\title{
INCONSISTENCY OF THE PRINCIPLES OF WRITING VARIETY ON THE WHATSAPP INSTANT MESSAGING APPLICATION
}

\author{
Nicky Rosadi ${ }^{1}$, Yulian Dinihari² \\ ${ }^{1}$ Program Studi Pendidikan Ekonomi, Fakultas Ilmu Pendidikan dan Pengetahuan Sosial, \\ Universitas Indraprasta PGRI \\ ${ }^{2}$ Program Studi Pendidikan Biologi, Fakultas Matematika dan Ilmu Pengetahuan Alam, \\ Universitas Indraprasta PGRI

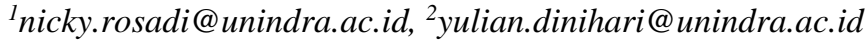

\begin{abstract}
Abstrak
Penelitian ini bertujuan untuk membahas inkonsistensi prinsip ragam tulis yang terjadi pada aplikasi pesan instan WhatsApp. Metode yang digunakan dalam penelitian ini ialah metode kualitatif dengan menggunakan teknik analisis deskriptif. Objek dalam penelitian ini ialah teks percakapan pada aplikasi pesan instan WhatsApp yang diambil secara acak dan kemudian didokumentasikan dalam bentuk gambar sehingga obrolan dapat terekam secara visual. Hasil penelitian menunjukkan bahwa, terdapat inkonsistensi prinsip ragam tulis pada aplikasi pesan instan WhatsApp yang menyebabkan bentuk ragam ini tidak dapat seutuhnya dikatakan lagi sebagai ragam tulis. Inkonsistensi ini terlihat pada saat pembuka obrolan, sebanyak 93\% dari data yang ada, pengirim pesan menggunakan ragam tulis dengan prinsip yang utuh. Namun, saat mendapat balasan dan terjadi percakapan, 97\% data menunjukkan, prinsip ragam tulis tidak lagi diterapkan secara utuh. Didapatkan bahwa pengirim pesan menjawab dengan menggunakan struktur kalimat yang tidak utuh dan terdapat penghilangan unsur, baik subjek, predikat, objek, maupun keterangannya. Selain itu, ditemukan juga beberapa data yang menunjukkan bahwa dalam penyampaiannya, pengirim pesan terkadang menggunakan emoticon tertentu sebagai upaya membangun konteks, yang dalam ragam lisan biasanya diakomodasi oleh gestur dan mimik wajah. Berkenaan dengan hal tersebut, peneliti berkesimpulan bahwa ragam yang muncul pada aplikasi pesan instan WhatsApp ini tidak bisa dikatakan lagi sebagai ragam tulis. Akibat inkonsistensi penerapan prinsip ragam tulis dan lisan ini, maka penulis menyarankan ragam yang muncul pada aplikasi pesan instan ini disebut sebagai ragam inlis.
\end{abstract}

Kata Kunci: ragam bahasa; ragam tulis; ragam lisan; WhatsApp.

\begin{abstract}
This study aims to discuss the inconsistency of the principle of writing style that occurs in the WhatsApp instant messaging application. The method used in this study is a qualitative method using descriptive analysis techniques. The object in this study is the text of the conversation on the WhatsApp instant messaging application which is taken randomly and then documented in the form of images so that the chat can be recorded visually. The results of the study show that, there is an inconsistency of the principle of writing style in the WhatsApp instant messaging application which causes this form of variety to not be fully said to be a type of writing. This inconsistency is seen at the time of opening the chat, as much as $93 \%$ of the existing data, the sender of the message uses a written variety with intact principles. However, when a reply was received and a conversation took place, $97 \%$ of the data showed that the principle of writing style was no longer fully applied. It was found that the sender of the message answered by using a sentence structure
\end{abstract}


that was incomplete and there were omissions of elements, both subject, predicate, object, and description. In addition, it was also found some data showing that in their delivery, the sender of the message sometimes uses certain emoticons as an effort to build context, which in the spoken variety is usually accommodated by gestures and facial expressions. In this regard, the researcher concludes that the variety that appears on the WhatsApp instant messaging application can no longer be said to be a written variety. Due to the inconsistency of applying the principles of written and spoken variety, the authors suggest that the variety that appears in this instant messaging application is called the inlis variety.

Keywords: variety of languages; written variety; spoken variety; WhatsApp.

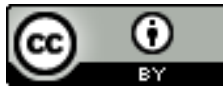

Creative Commons Attribution 4.0 International (CC BY 4.0)

\section{PENDAHULUAN}

Seiring perkembangan zaman, manusia hidup dan berkomunikasi dengan teknologi yang canggih. Perkembangan teknologi ini tidak hanya mengembangkan dan meningkatkan sesuatu yang sudah ada sebelumnya, namun juga kadang menciptakan sesuatu yang sebelumnya tidak terpikirkan. Jika dilihat ke belakang, dahulu manusia hanya mampu berjalan kaki untuk berpindah dari satu tempat ke tempat lain. Kemudian beralih menaiki hewan di darat, menggunakan alat untuk mengambang di atas air, hingga akhirnya bisa melayang di atas awan. Perkembangan ini awalnya terasa mustahil, namun kini, semua sudah biasa-biasa saja. Menggunakan motor atau mobil di darat, mengapung dengan kapal atau jetski, hingga terbang menggunakan pesawat atau helikopter, telah menjadi sesuatu yang lumrah di kalangan manusia modern seperti sekarang ini.

Perkembangan ini juga terasa pada penggunaan bahasa dalam berkomunikasi. Jika sebelumnya manusia hanya dapat bertukar suara sampai akhirnya ditemukan tulisan, manusia kini sudah bisa saling mengobrol tanpa harus saling bertatap muka. Informasi yang semula hanya dapat disebarkan dalam lingkup yang terbatas, kini dapat menyebar ke seluruh pelosok negeri dalam waktu yang singkat. Keterbukaan informasi ini semakin pesat perkembangannya saat manusia mulai menggunakan internet.

Dampak ini terasa sekali di dunia pendidikan. Pengguna internet di kalangan mahasiswa termasuk dalam kategori heavy user (Novianto, 2011). Biasanya mereka menggunakan internet sebagai bahan referensi dalam mencari informasi juga menjalin hubungan sosial. Karena dapat memberikan pengetahuan baru dan mampu menjalin hubungan sosial tanpa harus bertatap muka, hal-hal yang terhubung dengan internet menjadi pilihan mahasiswa saat hendak meng-update ilmu, pengetahuan, dan kemahiran mereka (Kassim \& Ahmad, 2010). Tak ayal, pemaksimalan penggunaan teknologi dalam jaringan internet pun dilakukan, termasuk dalam pembelajaran.

Hal ini begitu terlihat pada era pandemi Covid-19 dalam pelaksanaan pembelajaran jarak jauh. Bukan hanya pembelajarannya, komunikasinya pun ikut berpindah ke ranah maya. Di dalam jaringan, pertukaran informasi dan komunikasi diwujudkan dalam bentuk tulisan, video, atau gambar (Chano \& Paramita, 2019). Hampir semua orang berinteraksi dan mengobrol via internet dengan menggunakan aplikasi obrolan online seperti WhatsApp, Telegram, Line, dan lain sebagainya (Megayanti \& Rosadi, 2018). Selain itu sebuah penelitian mengungkapkan bahwa sebanyak $89 \%$ mahasiswa menggunakan aplikasi obrolan WhatsApp (Megayanti, 2021). Hal ini 
membuktikan bahwa WhatsApp begitu mendominasi digunakan dalam komunikasi di ranah maya. Berdasarkan hal tersebut, maka penelitian ini bermakasud untuk membahas penerapan prinsip ragam tulis pada aplikasi pesan instan WhatsApp.

\section{METODE PENELITIAN}

Metode dalam penelitian ini yaitu metode deskriptif kualitatif dengan teknik analisis isi. Pengumpulan data dalam penelitian ini dilakukan dengan mengidentifikasi ciri ragam bahasa tulis yang terdapat di dalam teks obrolan mahasiswa yang dilakukan pada aplikasi pesan instan WhatsApp. Peneliti mengambil obrolan mahasiswa secara acak dan berhasil mengumpulkan 88 obrolan yang telah didokumentasikan dalam bentuk gambar. Langkah-langkah yang dilakukan dalam penelitian ini yaitu (Miles \& Huberman, 1992):

\section{Reduksi Data}

Peneliti membaca secara keseluruhan data yang sudah ditentukan. Setelah isi teks tersebut dipahami secara keseluruhan, peneliti membaca kritis teks obrolan instan dalam rangka memperoleh penghayatan dan pemahaman terhadap seluruh ini teks. Peneliti membaca teks secara merinci, memilah-milah, menyeleksi, dan menggolongkan/mengelompokkan ragam dari teks tersebut. Hal ini dilakukan agar memudahkan peneliti dalam menentukan ciri ragam dari setiap obrolan tersebut.

\section{Penyajian data}

Penyajian data analisis menggunakan tabel analisis setiap ciri ragam untuk dapat melihat penerapan prinsip ragam yang terdapat dalam teks obrolan.

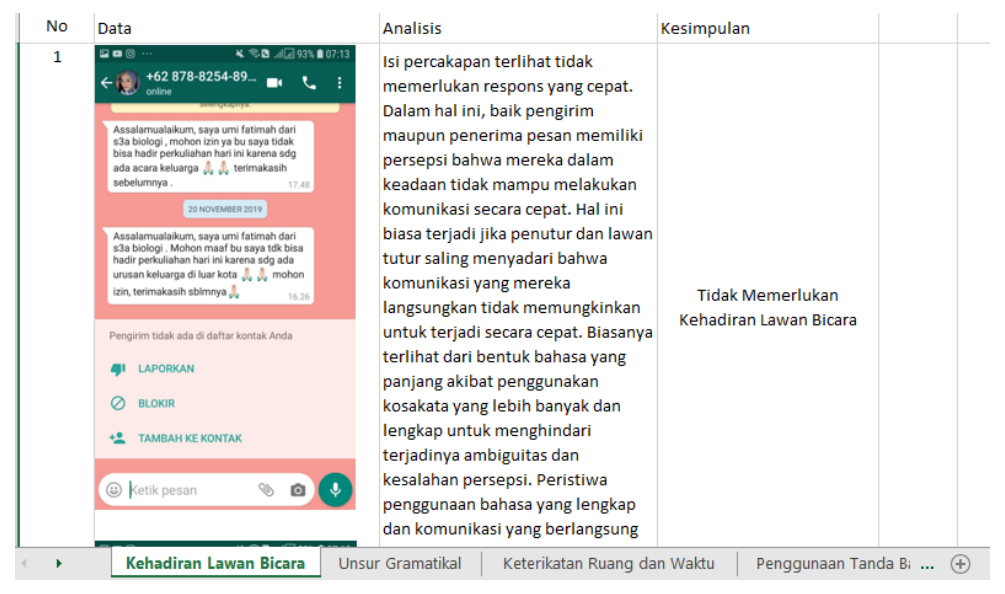

Gambar 1 Contoh tabel analisis ciri ragam bahasa tulis

\section{Penarikan Kesimpulan}

Penarikan kesimpulan dilakukan selama proses penelitian berlangsung.

\section{HASIL DAN PEMBAHASAN}

Hasil

Berdasarkan penelitian yang dilakukan, maka diketahui bahwa dari 88 jumlah data yang ada, $100 \%$ data memulai obrolan dengan menggunakan struktur bahasa yang lengkap. Hal ini terlihat pada salah satu contoh data berikut. 


\section{Assalamualaikum \\ Selamat malam bu. \\ Mohon maaf mengganggu waktunya. \\ Saya Rahiqi Makhtum dari kelas S1B mau \\ izin tidak masuk kelas anda karna sakit. \\ Sekali lagi saya mohon maaf tidak bisa masuk kelas ibu malam ini.

Gambar 2. Contoh pesan instan berstruktur gramatikal lengkap

Dari contoh data tersebut, dapat kita lihat bahwa struktur gramatikal yang digunakan lengkap. Dapat terlihat subjek ("Saya Rahiqi Maktum"), predikat ("izin tidak masuk kelas anda"), dan keterangan sebab ("karena sakit"). Selain lengkap secara gramatikal, data juga memperlihatkan prinsip-prinsip kesantuaan berbahasa di antaranya; (1) maksim kebijaksanaan; (2) maksim kedermawanan; (3) maksim penghargaan; (4) maksim kesederhanaan; (5) maksim permufakatan; dan (6) maksim simpati (Sujiono, 2021).

Namun, komunikasi yang terjadi ternyata tidak memperlihatkan konsistensi penerapan prinsip ragam tulis, seperti yang terlihat dalam gambar berikut.

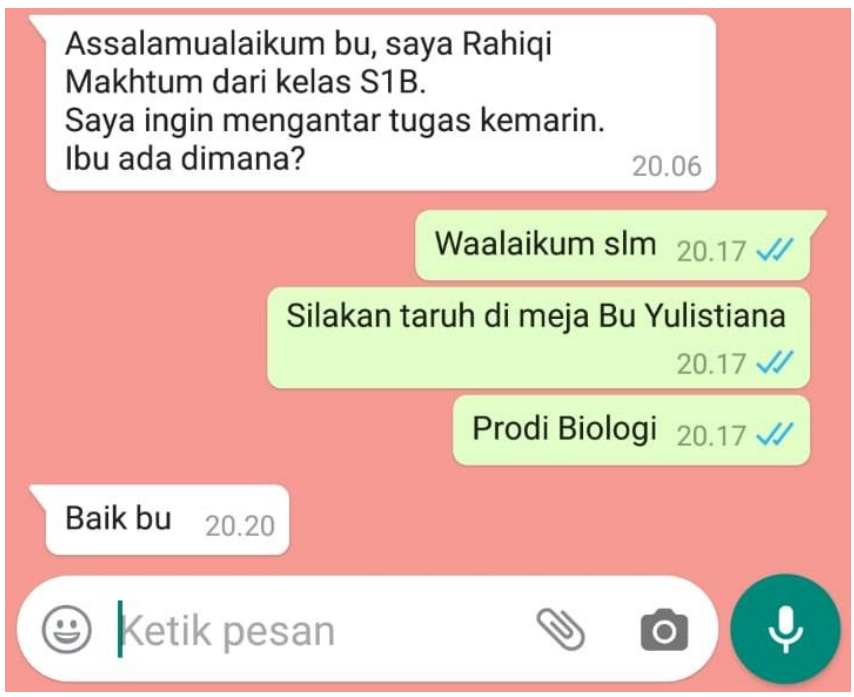

Gambar 3 Ketidakkonsistenan prinsip ragam tulis

Pada gambar terlihat, ketika komunikasi terjadi, penutur yang semula menggunakan prinsip ragam tulis dengan lengkap, kemudian merespons dengan kalimat yang mengalami penghilangan unsur gramatikalnya. Tidak dapat diidentifikasi subjek dari kalimat "Baik bu". Alih-alih menjawab dengan lengkap, seperti "Baik, Bu, Saya akan meletakkan tugas kemarin di meja Bu Yulistiana", penutur merasa cukup menjawab dengan singkat dan menghilangkan struktur lengkapnya. Temuan ini, terjadi pada 49 
$(55,7 \%)$ dari data yang ada. Sisanya, tidak terjadi hal ini karena percakapan tidak dibalas oleh penerima pesan.

Selain itu, ditemukan juga $32(36 \%)$ data yang di dalamnya terdapat emoticon dalam percakapan. Emoticon bisa digunakan antara lain untuk mempertegas isi pesan, memberikan dukungan, menyidir seseorang, pengungkapan perasaan sedih, mengungkapkan perasaan malu, untuk memberikan semangat, untuk permohonan maaf, untuk mengungkapkan perasaan kecewa, dan untuk mengungkapkan perasaan syukur (Purnomo \& Muhibbin, 2018). Dalam hal ini, pemberian emoticon dimaksudkan untuk membangun konteks dalam percakapan.

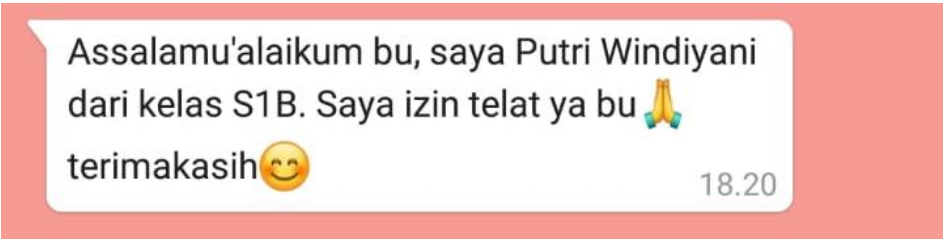

Gambar 4 Penggunaan emoticon dalam percakapan di WhatsApp

\section{Pembahasan}

Adanya ragam bahasa lisan dan ragam bahasa tulis didasarkan pada kenyataan bahwa bahasa lisan dan tulis memiliki struktur yang tidak sama (Chaer \& Agustina, 2004). Ketidaksamaan ini terjadi akibat adanya unsur nonsegmental atau unsur nonlinguistik yang berupa nada, gesture, mimik wajah, dan gejala fisik lainnya yang muncul saat seseorang menggunakan ragam lisan. Hal-hal tersebut tentu saja tidak dapat ditemukan dalam ragam tulis.

Ragam tulis memiliki ciri-ciri; (1) Tidak memerlukan kehadiran orang lain; (2) Unsur gramatikal dinyatakan dengan lengkap; (3) Tidak terikat ruang dan waktu; dan (4) Dipengaruhi oleh tanda baca dan ejaan (Anam \& Rosadi, 2016). Berdasarkan pernytaan ini maka dapat dipahami bahwa ragam tulis hanya dipengaruhi oleh tanda baca dan ejaan. Tanda baca dan ejaan inilah yang kemudian membangun makna yang terkandung dalam tulisan tersebut. Sehingga, tulisan dapat dibaca kapan saja tanpa harus memperhatikan konteksnya. Hal ini berbeda dengan ciri ragam lisan, yaitu: (1) Memerlukan kehadiran orang lain; (2) Unsur gramatikal tidak dinyatakan secara lengkap; (3) Terikat ruang dan waktu; dan (4) Dipengaruhi oleh nada, gesture, mimik wajah, dan gejala fisik lainnya (Anam \& Rosadi, 2016; Chaer \& Agustina, 2004).

Namun, berdasarkan temuan yang ada, prinsip ini berlaku hanya ketika percakapan dimulai. Karena, setelah percakapan terjadi, banyak prinsip ragam tulis yang tidak lagi berlaku. Seperti gambar berikut. 


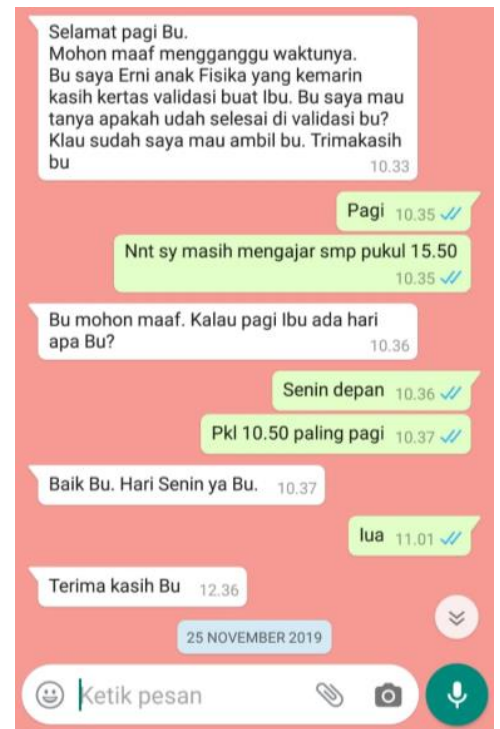

Gambar 5 Dokumentasi percakapan di WhatsApp

Dari gambar, terlihat bahwa percakapan terjadi dengan banyak penghilangan unsur gramatikal. Meski secara wujud percakapan dijawantahkan dalam bentuk tulis, namun secara prinsip, penghilangan unsur dilakukan demi efisiensi komunikasi. Padahal, secara prinsip, penghilangan unsur gramatikal hanya dimaklumkan terjadi pada ragam lisan sebagaimana ciri-ciri ragam yang telah dibahas sebelumnya.

Jika diperhatikan secara saksama, penghilangan unsur baru terjadi saat penerima pesan merespons pesan dari si pengirim. Hal ini berarti, terdapat peralihan persepsi dari si pengirim pesan. Jika semula pengirim menganggap pesannya tidak akan direspons dengan segera, maka untuk itu si pengirim perlu menuliskan informasinya dengan unsur gramatikal yang lengkap. Namun ketika pesannya direspons dan pengirim meyakini kehadiran penerima pesan, prinsip beralih menjadi penerapan prinsip ragam lisan yang di antaranya: (1) memerlukan kehadiran orang lain; dan (2) penghilangan unsur gramatikal. Meski secara wujud percakapan masih berupa ragam tulis, namun penerapan prinsipnya beralih menjadi prinsip ragam lisan demi efisiensi waktu percakapan.

Tersebab persepsi yang terbangun adalah prinsip ragam lisan, maka pengirim merasa perlu membangun konteks keakraban dengan membangun unsur nonsegmental dalam bentuk penggunaan emoticon. Emoticon yang biasanya mewakili gambaran perasaan si pengirim, disematkan juga dalam teks percakapan yang dikirimkan. Dalam hal ini, pengirim tidak lagi meyakini bahwa percakapan dalam ragam tulis sangat dipengaruhi oleh tanda baca dan ejaan, melainkan, sebagaimana prinsip ragam lisan, percakapan dipengaruhi oleh unsur nonlinguistik seperti gambar berikut. 


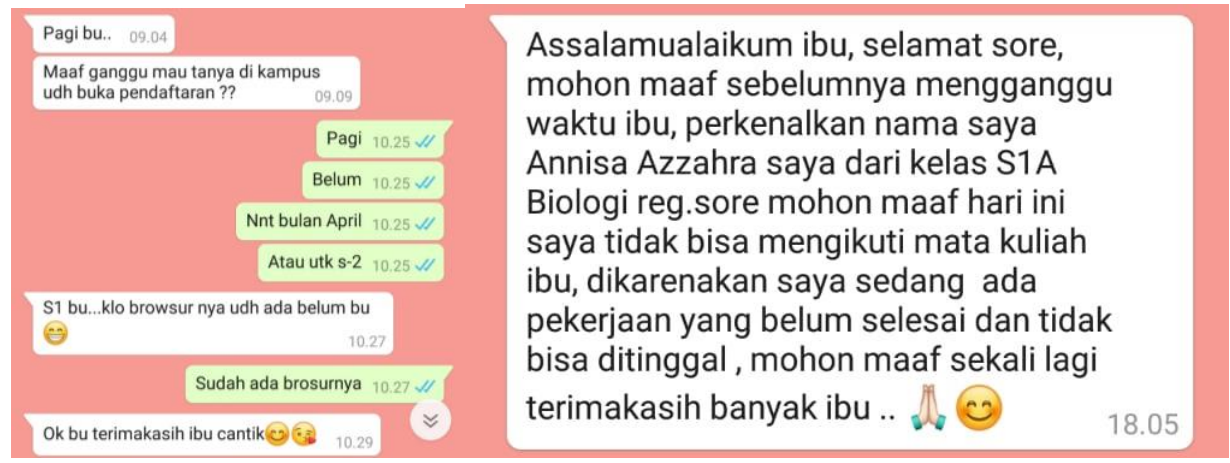

Gambar 6 Penggunaan emoticon sebagai upaya membangun konteks

Berdasarkan analisis yang dilakukan, peneliti mendapati bahwa ragam bahasa berdasarkan wujudnya, yang digunakan dalam aplikasi obrolan instan WhatsApp ternyata secara prinsip tidak konsisten menerapkan ragam bahasa tulis. Meski berwujud tulisan, dalam pelaksanaannya, secara prinsip hampir sebagian besar menerapkan ragam bahasa lisan. Percakapan di aplikasi obrolan WhatsApp dapat dilakukan dengan atau tanpa kehadiran orang yang diajak berkomunikasi. Artinya, layaknya surat, pesan WhatsApp dapat dibaca oleh penerima pesan kapan saja. Begitu pun respons yang dilakukan, penerima pesan dapat langsung membalas percakapan dan percakapan berlangsung dengan cepat jika memang antara pengirim dan penerima pesan dalam keadaan yang sama-sama dapat merespons pesan tersebut.

Dalam percakapan di WhatsApp, unsur gramatikal tidak selalu dinyatakan lengkap. Karena percakapan yang berwujud teks, maka baik pengirim maupun penerima pesan akan dapat terus membaca pesan-pesan yang disampaikan sebelumnya. Ketidaklengkapan unsur gramatikal yang terjadi dapat dimaklumi dengan alasana efisiensi percakapan. Bahkan, terkadang, pengirim dan penerima pesan saling menggunakan slang dalam bentuk dasar, frasa, bahkan klausa. Hal ini sesuai dengan penelitian terdahulu bahwa slang ditemukan pada tuturan anggota grup WhatsApp (Putri et al., 2021).

Sebagaimana ragam lisan, maka gesture dan mimik wajah menjadi hal dominan dalam berkomunikasi, selain intonasi. Gesture dan mimik wajah dalam WhatsApp dapat difasilitasi melalui emoticon yang telah disediakan. Emoticon seperti wajah yang tersenyum dan tangan yang saling tertempel, pada dasarnya digunakan untuk memunculkan rasa sukacita dan hormat dari pengirim pesan kepada penerima pesan. Emoticon lain yang juga digunakan pada dasarnya bertujuan untuk membangun konteks dari teks yang dikirimkan. Namun, perlu dipahami bahwa seyogiayanya penggunaan emoticon haruslah memiliki kesamaan persepsi agar tidak terjadi kesalahpahaman. Hal ini sesuai dengan penelitian yang dilakukan oleh peneliti sebelumnya bahwa makna dari suatu emoticon dapat berbeda tergantung dari pesan yang menyertainya (Abidin, 2016). Selain itu, faktor eksternal seperti konteks sosial, beragama, budaya, dan sebagainya. Sebuah kelompok kecil mampu untuk membuat makna tersendiri dari suatu lambang emoticon, tergantung dari kesepakatan anggota dalam kelompok tersebut.

\section{SIMPULAN}

Berdasarkan penelitian yang dilakukan, maka dapat disimpulkan bahwa terdapat ketidakkonsistenan (inkonsistensi) penerapan prinsip ragam tulis pada aplikasi pesan instan WhatsApp. Meski diwujudkan dalam bentuk tulis, namun ternyata sebagian besar prinsip yang 
diterapkan adalah prinsip ragam lisan. Prinsip yang terjadi pada aplikasi pesan instan WhatsApp yaitu (1) Percakapan dapat dilakukan dengan/tanpa kehadiran orang lain; (2) Unsur gramatikal tidak selalu dinyatakan secara lengkap; (3) Informasi yang disampaikan tidak terikat ruang dan waktu (dapat dibaca kapan saja); dan (4) Penyematan emoticon dapat dilakukan sebagai upaya membangun konteks percakapan.

Berdasarkan simpulan tersebut, maka dapat dikatakan bahwa ragam bahasa ada pada aplikasi pesan instan WhatsApp tidak dapat lagi dikategorikan wujudnya sebagai ragam tulis atau ragam lisan. Pertimbangan ini muncul lantaran wujud dan prinsip yang secara tidak konsisten diaplikasikan pada percakapan di aplikasi pesan instan tersebut. Mempertimbangkan ketidakkonsistenan (inkonsistensi) itu dan akar kata yang sama pada lisan dan tulis (akar kata lis), maka penulis menyarankan penamaan ragam inlis untuk ragam bahasa berdasarkan wujudnya yang terjadi di dalam aplikasi obrolan instan. Tentu saja hal ini perlu diperkuat oleh dukungan para ahli serta penelitian lebih lanjut terkait masalah ini.

\section{DAFTAR PUSTAKA}

Abidin, Y. (2016). Makna lambang-lambang emoticon (Analisis semiotika lambang-lambang emoticon di whatsapp messenger dalam kegiatan chatting mahasiswa Universitas Muhammadiyah Ponorogo). Universitas Muhammadiyah Ponorogo.

Anam, A. K., \& Rosadi, N. (2016). Bahasa Indonesia masa kini (Untuk mahasiswa kekinian). PT Pustaka Mandiri.

Chaer, A., \& Agustina, L. (2004). Sosiolinguistik: Perkenalan awal, Edisi Revisi. PT Rineka Cipta.

Chano, T. M., \& Paramita, S. (2019). Transformasi komunikasi politik melalui media sosial instagram (Studi terhadap Akun @karyaadalahdoa). Koneksi, 3(1), 176. https://doi.org/10.24912/kn.v3i1.6201

Kassim, Z. B., \& Ahmad, A. R. Bin. (2010). E-Pembelajaran: Evolusi Internet dalam pembelajaran sepanjang hayat. Proceedings of Regional Conference on Knowledge Integration in ICT, 210. http://library.oum.edu.my/oumlib/sites/default/files/file_attachments/odlresources/159456/epembelajaran.pdf

Megayanti, W. (2021). Analisis kepuasan mahasiswa dalam proses pembelajaran melalui aplikasi obrolan online. INTELEKTIUM, 2(1), 54-60. https://doi.org/10.37010/int.v2i1.285

Megayanti, W., \& Rosadi, N. (2018). Pengaruh kepemilikan handphone terhadap uang saku peserta didik untuk pembelian pulsa paket internet di SMK Yamas Jakarta. Research and Development Journal of Education, 5(1), 25. https://doi.org/10.30998/rdje.v5i1.3386

Miles, M. B., \& Huberman, A. M. (1992). Analisis data kualitatif. Terjemahan Tjetjep Rohendi Rohidi. Penerbit Universitas Indonesia.

Novianto, I. (2011). Perilaku penggunaan internet di kalangan mahasiswa. IIK. http://www.journal.unair.ac.id/filerPDF/Jurnal IIK Novianto.pdf

Purnomo, A. C., \& Muhibbin, A. (2018). Analisis semiotika terhadap penggunaan emoticon whatsapp dalam komunikasi interpersonal antar mahasiswa ilmu komunikasi angkatan 2013. Universitas Muhammadiyah Surakarta.

Putri, D. M., Muzammil, A. R. U., \& Syahrani, A. (2021). Analisis bentuk dan pola pembentukan ragam slang pada media sosial whatsapp. Jurnal Pendidikan Dan Pembelajaran Khatulistiwa, 10(4).

Sujiono, S. (2021). Pergeseran budaya kesantunan berbahasa mahasiswa terhadap dosen melalui media sosial whatsapp. Maha Widya Bhuwana: Jurnal Pendidikan, Agama Dan Budaya, 3(2), 139-146. http://jurnal.stahnmpukuturan.ac.id/index.php/bhuwana/article/view/952 